\section{Young wisdom}

\author{
Gary K. Meffe
}

My last two 'Savannah Perspectives' have been, on the whole, rather pessimistic about the status of conservation and our prospects for continued species and ecosystem protection in the USA. In July I discussed the 'disinformation age' that guides much of our decision-making these days, a communication approach fuelled by desires for power and wealth by some special interest groups, and enabled by blatant disregard for scientific truth. In October I presented a rather unflattering image of the US Congress. It is in the process of turning back the clock several decades and returning to the 'good old days' of lax environmental regulation, permitting excessive natural resource exploitation for immediate profit by a few, while passing costs on to many; the tragedy of the commons may define our near future. It is easy to be pessimistic now, with decisions being driven (mostly) by middle-aged to decadent white males who know little of ecological values, care less about species diversity or fair play, and are driven by value systems as calloused and hardened as the cholesterol lining their ageing coronary arteries. Where is a caring person to turn for hope and optimism? Is there any reason for such?

Three recent experiences tell me there is indeed hope, and all were brought to me by young people. The first occurred while my wife, Nancy, and I were birding at a small nature sanctuary on the South Carolina coast last summer. In our typically excited but measured style, we were slowly making our way from the parking lot through a salt marsh to some clumps of trees where in the past we had seen a good diversity of birds. Along the trail we observed the fiddler crabs scampering into their burrows on the mud flats, looked for raptors and egrets over the marshes, smelled the characteristic salt-marsh decay, and listened for songs from nesting birds. In short, we opened ourselves to all the experiences offered by that bit of local diversity.
In direct contrast, heading back to the parking lot in an obvious hurry, was a woman with two young girls, perhaps 9 and 11, in tow. The woman was moving them along as quickly as possible, and in fact walked right under a nest of blue-grey gnatcatchers, oblivious to the activities of the young birds or their mother. This woman was also unaware of the carpenter bees they passed along the trail, the green anole basking on a $\log$, the raccoon lurking at the edge of the marsh, or the boat-tailed grackles and red-winged blackbirds proclaiming their territorial rights; she simply wanted to get back to the car now, and needed to move her girls along. As they passed us we caught a snippet of their conversation, and I reproduce it here verbatim. Older daughter: 'But Mom, what's the point of a nature walk if we can't stop and look at nature?' Mother's response: 'Look at it quickly as you go by'.

What a terrible lesson to teach a bright young mind that is reaching out to other species and new experiences. This girl, who was ready and willing to embrace natural complexity, was stifled and instead was taught that nature should be encountered, if at all, on the run and at no inconvenience to larger plans. Lesson learned? If you can catch sight of nature while hurrying along, great; if not, well, nature is not very important to us anyway. This girl was deprived of a pleasant and possibly important experience in her development. But the more important point is that she realized that there was something valuable to be seen, heard and smelled. The desire was there, perhaps even an innate desire. That provides hope, and I suggest she had more wisdom than her poor, myopic mother. If not discouraged too often, perhaps this girl will begin to take the time needed to look at nature and not just 'catch it as it goes by'. Perhaps, despite her mother's careless attitude towards the wonderful experiences that my wife and I were treated to, that girl will go on to wonder about those bees or that lizard, their roles in the world and their contributions to the physical and spiritual welfare of humanity. I know I cannot live without them and maybe she will not be able to either.

The second event occurred later in the (C) $1996 \mathrm{FFI}$, Oryx, $30(1)$ 
summer, in the town of Banff, Alberta, Canada. During an afternoon in a beautiful Victorian-style zoology museum, amidst the old and well-cared-for specimens of birds and mammals and the wonderful collections of birds' eggs, we came across a very striking chalkboard. On this board, among the skins, charts and small chairs in an education room obviously used for school-children, was written the following question: Why is wildlife important to you?' I reproduce the answers here exactly as they appeared:

- Everyone is connected in a chain - even us. Erik.

- God gave man dominion over the animals, and with that comes the responsibility to preserve, as well as the privilege to use.

- Because I love animals. Mia.

- It is life and all life should be taken care of.

- I love animals and respect life.

- I love animals, and I think everyone should respect animals (sic) life. Lauren.

- God gave animals to us for a purpose - to care for and to love. We must learn to respect wildlife and that's important.

- For life.

Indeed, for life. These responses by young people demonstrate an innocent insight, one that seems lost in most adults. A strong respect for other life forms is evident, a respect that adults, especially those engaged in exercises of power or wealth, quickly lose and even loathe and ridicule.

Finally, a colleague at the International Crane Foundation in Baraboo, Wisconsin, Dr Curt Meine, recently shared a letter he received from an 11-year-old visitor named Erin. At this tender age, Erin was quite concerned about bird extinctions and what was being done to address the situation. Among her thoughts was the following observation: 'I believe that each person and animal has something special about them and when it is lost, it is missed'. How profound in its simplicity. What more motivation to protect and maintain nature does humanity need than that humble insight?

These wonderful children, with deep sensitivity and with values advanced beyond simple-minded power and wealth, do understand what is missed when species are lost. These young minds, not yet tainted by adult experiences, seem to know the true values of the natural world - both utilitarian and spiritual. In their unassuming but powerful ways, these young people move and motivate me in a way that no politician or business leader or even scientist possibly can. Their unfiltered thoughts speak volumes, which in some ways are far wiser than the rhetoric coming out of all the world's capitals and all the scientific conferences. Their inexperience with power and wealth - the base values that drive much of the modern world - gives them the freedom to embrace other, perhaps more rewarding perspectives that can better serve them in the long run: diversity, complexity, compassion, esteem, affection, community, belonging. Perhaps they even understand, in a simple way, that they are part of a larger, interconnected whole that is to be respected and loved rather than conquered and destroyed. They have young wisdom and they still care. The critical question is, will enough adults listen and be willing to learn from them?

Gary Meffe is an Associate Professor at the University of Georgia and the Savannah River Ecology Laboratory, and is senior author of Principles of Conservation Biology (Sinauer Associates, 1994). 